\title{
The interest group process
}

Between elections, the interest group process (along with media and social media coverage) is a key way in which citizens can seek to communicate with their MPs and other representatives, and to influence government policy-makers. Patrick Dunleavy considers how far different social groups can gain access and influence decision-makers. How democratically does this key form of input politics operate? And how effectively are all UK citizens' interests considered?

\section{How should the interest group process operate in a liberal democracy?}

$\checkmark$ Elected representatives and politicians should recognise a need for continuous consultation and dialogue with different sections of the public over detailed policy choices. Procedures for involving interest groups in decisions affecting them should cover the full range of stakeholders.

The resources for organising collective voices and political action in pressure groups, trade unions, trade associations, non-governmental organisations, charities, community groups and other forms should be readily available. In particular, decision-makers should recognise the legitimacy of autonomous collective actions and mobilisations by different groups of citizens.

$\downarrow$ The costs of organising effectively should be low and within reach of any social group or interest. State or philanthropic assistance should be available to ensure that a balanced representation of all affected interests can be achieved in the policy process.

$\downarrow$ Decision-makers should recognise inequalities in resources across interest groups, and discount for different levels of 'organisability' and resources.

$\downarrow$ Policy-makers should also re-weight the inputs they receive so as to distinguish between shallow or even 'fake' harms being claimed by well-organised groups, and deeper harms potentially being suffered by hard-to-organise groups. 
Other aspects of liberal democratic processes, such as the 'manifesto doctrine' that elected governments should implement all components of their election programmes, do not over-ride the need to consult and listen in detail to affected groups, and to choose policy options that minimise harms and maximise public legitimacy and consensus support.

$\downarrow$ Since policy-makers must sometimes make changes that impose new risks and costs across society, they should in general seek to allocate risks to those groups most easily or able to insure against them.

Between elections, the interest groups process generates a great deal of useful and perhaps relatively reliable information for policy-makers about preference intensities. By undertaking different levels of collective action along a continuum of participation opportunities, and incurring costs in doing so, ordinary citizens can accurately indicate how strongly they feel about issues to decision-makers.

Actions like sending back a pre-devised public feedback form, writing to an MP, supporting an online petition to the government, or tweeting support for something, are cheap to do and so only indicate a low level of commitment. Joining (and paying membership fees to) an interest group or going to meetings shows more commitment, and gives the group legitimacy and weight with politicians. Going on strike or marching in a demonstration indicates a higher level of commitments still. A well-organised interest group process will allow for a huge variety of ways in which citizens can indicate their views.

From a somewhat elderly 2006 study, we know that in the UK there were over 7,800 interest groups registered by group directories for the field. Jordan and Greenan demonstrate that business trade associations (many very small) were by far the greatest number, followed in numerical terms by professional groups and learned societies.

Campaigning and pressure groups ranked only fifth of their category types. Some individual groups have grown very large memberships in the millions or hundreds of thousands such as the UK's few trade unions, which have coalesced into a few very large membership bodies, or the National Trust or Royal Society for the Protection of Birds.

As Figure 1 shows, four out of five interest groups recruited individual members, and three out of five only recruited individuals - so their significance for elected politicians was based quite heavily on their size. Those that can engage the participation of almost all the people in a given occupation or role will carry especial weight, as with the well-organised medical professions. Over time the numbers of non-business groups (with individual memberships) grew substantially from 1970 to 2006, as the table part of Figure 1 shows. Campaigning groups grew slightly more in numbers than the general trend.

The remaining fifth of interest groups (all of them business or trade associations) only recruited firms as members, and a further fifth recruited both firms and individual members. Here legitimacy may be based on what proportion of a given industry or type of business are engaged with bodies claiming to represent them. Often rather divergent voices have claimed to represent business interests - as in the long-run rivalry between the Confederation of British Industry (CBl; which represents big firms and operates in a 


\section{Figure 1: The distribution of UK interest groups in 2006}
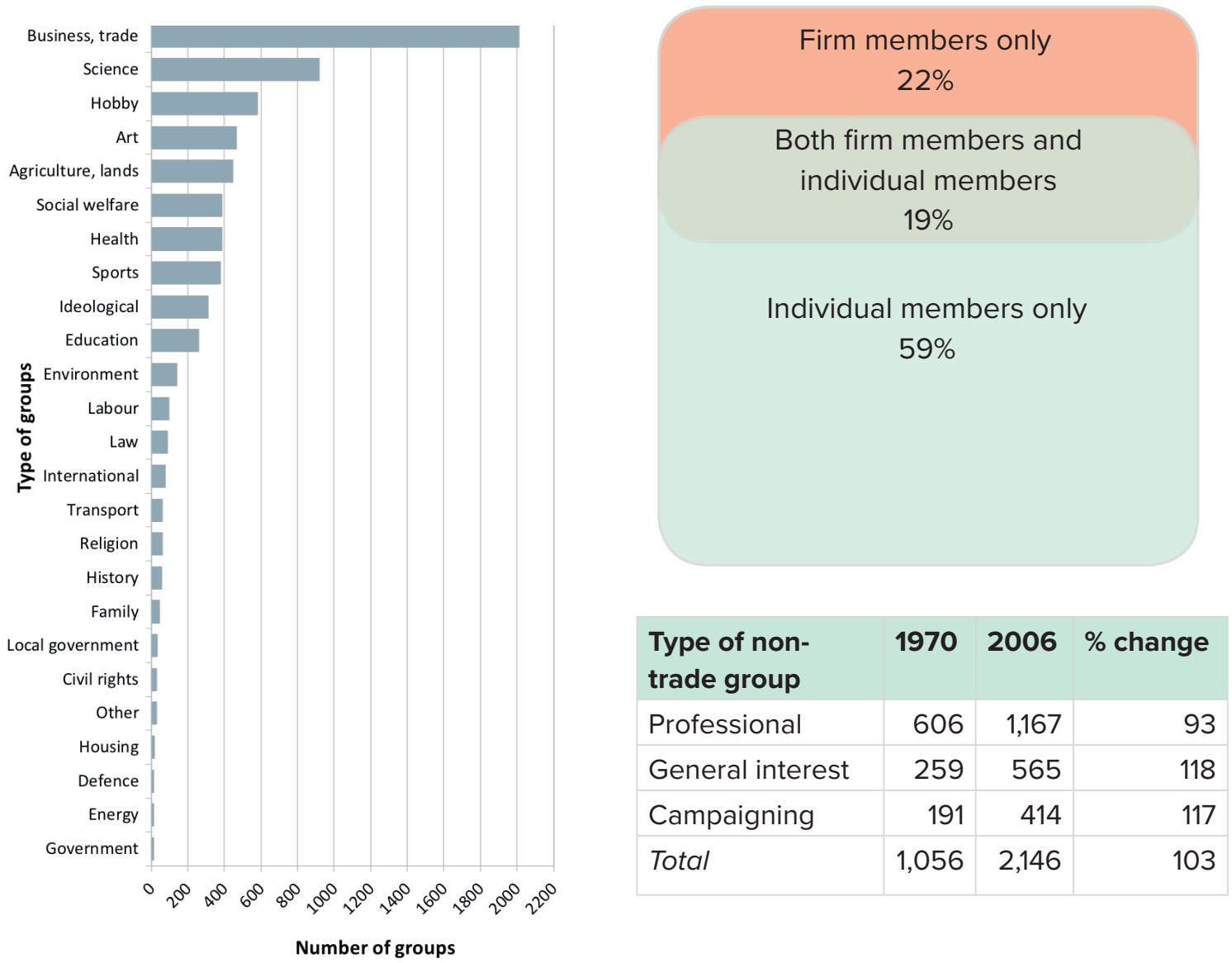

Source: Jordan et al, 2012, Table 7.2, p. 151, \& Jordan \& Greenan, 2012 Figure 4.1 p.82 \& p.92.

politically neutral, corporatist way) and the Institute of Directors (which is more eclectic and more right wing). Some industries are dominated by a single interest group, like the National Farmers' Union, which in the past achieved enormous insider influence with the relevant Whitehall department. Other looser coalitions of different interests (like the 'roads lobby' of transport operators, construction companies and motorist organisations) can achieve a similar dominance, however.

At any given time, an 'ecology' of interest groups operates, with different organisations competing for attention, and encouraging their members to commit more resources or time to the group. Trade unions have been the biggest and most continuous losers since the 1980s. Their membership numbers radically reduced with the decline of manufacturing industry and large firms. Numbers and unionisation rates held up better in the public sector, but even there, members became markedly less willing to go on strike in recent years. Meanwhile environmentally aligned groups and NGOs (non-governmental organisations) have flourished. Some big groups that shifted away from restrictive 'legacy' modes of recruiting members and adopted digital approaches have increased their size radically, notably the Labour Party under Jeremy Corbyn. But in the interest group world at large, such effects have generally been smaller. 


\section{Recent developments}

This area of policy-making has been stable for many years, with occasional fringe scandals - a succession of which lead to the 2014 Lobbying Act. This introduced an official register of paid lobbyists contacting MPs in Westminster and in touch with Whitehall departments, affecting commercial lobbying firms most, together with some groups with developed governmental or parliamentary liaison operations. The lobbying industry in the UK is estimated by some sources to be worth $£ 2$ bn a year, but still remains mostly self-regulated, especially perhaps in the new 'digital influencing' areas.

The large data analysis and lobbyist firm Cambridge Analytica became a focus of controversy in 2018 in the USA and Britain, after it emerged that it had extracted a large amount of users' personal data from Facebook without their knowledge, and used the information to construct sophisticated psychological profiles to target voters in the Trump campaign, and used by a closely allied company to help the Brexit Leave campaign. The firm fought a rearguard action against its critics, but it had to close down when its UK chair was caught on video in a 'sting' by a UK TV programme, boasting of using illicit influence techniques to ruin the reputations of rivals to its clients. With business clients drying up the firm shut its doors within a few days. The chief executive attended two grillings by a House of Commons select committee, and official investigations continued at the time of writing. Critics argued that the incident shone a light on lax regulation of new influence technologies, a conclusion that a Commons select committee shared in a critical mid-2018 report on fake news and social media.

Digital technologies could also play a role in allowing decision-makers to elicit and cheaply incorporate mass public views. The UK government re-established an official online petitions site in 2015, where citizens can lodge proposals for issues to be reviewed by Parliament. Any petition gaining 100,000 verified electronic signatures goes to the House of Commons and supposedly gets a debate, followed by a response. Very large numbers of petitions are started, but most quickly fail to attract public attention. Only those that can generate around 10,000 supporters in the first couple of days have any effective chance of reaching the 100,000 target in the time allowed. In 2016 thousands of petitions were started but only 10 reached the 100,000 threshold, and four of these were denied a parliamentary debate.

However, these initiatives can be influential. In spring 2017 Theresa May invited newly elected US President Donald Trump on a state visit to the UK. A petition to ban him quickly attracted 1.86 million supporters. Although ministers said that they would ignore this, the idea of a visit receded into the long grass until the summer of 2018. And when it did take place it was carefully organised to keep the famously touchy US President completely away from London and other UK cities where mass protests occurred. 


\section{Strengths, Weaknesses, Opportunities and Threats (SWOT) analysis}

\section{Current strengths}

British government ministers, MPs, politicians and civil servants recognise the importance and legitimacy of a vigorous interest group process. An open consultation process operates for all new legislation and government policy White Papers, and sometimes for statutory instruments.
Parliamentary processes, including the consideration of legislation, questions to ministers, and select committee hearings, connect strongly with the interest group process. Most legitimate or established groups can find MPs to represent their interests or cause, or to help from their position in the legislature. However, select committee inquiries access quite a restricted and biased range of 'recognised' interests. Public involvement processes in the devolved Scottish, Welsh, Northern Ireland and London legislatures/assemblies are generally far more systematic and inclusive.

UK decision-makers are alert to the potentially excessive power of lobbyists and of well-resourced groups best able to afford lobbyists and other organised and commoditised means of influence. Most (if not all) politicians discount heavily for the 'industrialised' lobby power of business and other wealthy groups. Lobbying is regulated and any excesses in attempting to secure influence are frowned upon and quickly stamped out - as the Cambridge Analytica case demonstrates.

\section{Current weaknesses}

Where interest groups are battling against party A's manifesto commitments, and especially where they are aligned with a rival party $B$, they will face an uphill struggle to make any changes in the incumbent government's policies. Governing parties in the UK have a strong record of pushing through partisan commitments, and over-riding the opposition of groups who do not support them. The UK has no equivalent of the European Union's formal reporting back of consultation outcomes. Ministers and civil servants commonly 'talk up' any support their proposals secure, while ignoring or belittling unfavourable feedback.

There are sharp inequalities in the capabilities of different social groups to monitor policy proposals and to get effectively involved in official consultation and legislative processes. The poorest and least socially resourced groups in British society rely chiefly on NGOs, charities and altruistic philanthropists to secure any research or campaigning on issues that concern them. By contrast, business interests have well-developed government and parliamentary liaison units, and ready access to professional lobbyists, public relations consultants, marketers and media experts - giving corporations and well-off elites inherent advantages that are hard to counteract.

Lobbying in the UK has historically focused most attention on creating private links with civil servants and ministers, exercised at early stages of the policy process, and often carried out without transparency. Concertation of ministerial decisions and business interests have been fuelled by incidents like the hundreds of emails between News International and the private office of the responsible minister, Jeremy Hunt, during a take-over battle he had to adjudicate in 2010-12. 


\section{Current strengths}

For elected politicians, what matters most is the vote-power of groups, which is a function of their size (large membership groups are more influential than small ones), the intensity of their preferences (groups that care a lot outweigh apathetic ones), and their pivotality (giving more importance to potential 'swing' groups who might shift support between parties, shaping who wins). There are inherent influence inequalities between groups, but because they derive essentially from their role in the electoral process, they are generally democratically defensible.

Saturation media coverage, and now social media coverage as well, means that the risks for politicians in lightly or overtly deferring to powerfully organised interests have increased. Modern policymaking has shifted more into cognitive modes of competition between rival coalitions of interests. Here the quality of evidence you can produce to back a case, and sustain effective participation in policy debates, counts for more than simple voting power or financial might. A more deliberative interest group process has emerged, which has evened up access to the policy terrain.

\section{Current weaknesses}

As the powers of the House of Commons committees have slowly grown, and coalition governments operated in hung parliaments in 2010-15 and 2017-present, so more lobbying has focused on the legislature. Because MPs and peers can work for outside jobs and take money from well-funded interests, there have been a succession of scandals around MPs, peers and even ministers not declaring interests.

For politicians the realpolitik of the interest group process is that they appease groups whose support they rely on. But they will cheerfully impose costs on groups normally opposed to them, or too small or poorly organised to do them electoral damage.

Both ministers and civil servants also routinely extract a 'good behaviour' price for conceding influence to any 'insider' group. To remain influential the group must only express critical views 'moderately' and privately, at early stages of policy development before proposals go public. They must normally mute any public criticisms altogether, or tone them down to be non-confrontational or expressed 'responsibly'.

Cognitive competition remains heavily influenced by resources and money. Wealthy interests can better afford to fund research and information gathering than groups representing the poor and powerless. Wealthy interests can also trigger more law cases in areas favourable to them and thus ensure that legal knowledge differentially develops in helpful ways. 


\section{Future opportunities}

The growth of social media and internet-based modes of organising has radically lowered the information and transaction costs of organising collective actions in the last two decades, and promises to continue doing so. In particular, large-scale citizen mobilisations by spatially dispersed or 'functional' groups (for example, patients affected by a particular disease, or citizens with a shared specialist interest) have become far more feasible and influential.

The mass emergence of 'clicktivism' allows individuals to spontaneously signal their position on public issues on Twitter, Facebook and other social media. These 'microdonations' of time and support mean that people get instant feedback on the popularity of their views and potentially linkages to like-minded people. This radically enhances the speed and granularity of the public's collective vigilance over policy-making in liberal democracies. However, more critical citizen activist campaigners like Alberto Alemmano stress that clicktivism cannot be an end in itself, but must be part of a wide armoury of modernised citizen engagement leading to 'real world' engagement.

Crowdfunding via the internet has increasingly emerged as a way that large and dispersed groups can fund previously difficult mobilisations. The anti-Brexit lobbyist Gina Miller used this technique to back anti-Brexit candidates in the 2017 general election, as did other satellite campaigns. (However, her more famous Supreme Court legal case against the government was privately funded.) Similarly, 'open source' techniques of organising can often help otherwise disadvantaged groups to operate more effectively in competition with business hierarchies.

Interest groups were keen to get involved in the Brexit negotiations, not least because they know a lot about the EU policy process - but pro-Remain industry interventions were fiercely attacked by Brexiteer politicians.

\section{Future threats}

Lobbying and public relations professionals have extended the techniques and services they use for commercial and other wellfunded interests so as to increasingly manipulate social media in expert ways. A new and powerful 'data-industrial complex' has recently emerged, as the Leave campaign for the Brexit referendum aptly demonstrated.

By increasingly 'delegating' the job of representing diverse relatively powerless societal interests to NGOs and charities, and restricting their own participation to digital means, well-educated and altruistic middle-class people have created another spiral in the further 'professionalisation' of democratic politics. Groups that slip between the gaps of NGOs' concerns (for example, perhaps 'Fathers for Justice') can lose out badly from this system. Their inexpert autonomous efforts to organise become ever more marginalised in the political world.

The virulent tone of the Brexit referendum campaign upset many charities. The chief executive of the National Council of Voluntary Organisations said he regretted they had not spoken out enough because of fear of running foul of the 2014 lobbying regulations, plus being pilloried in the media. In Brexit policy development up to summer 2018, ministers and Whitehall have seemed reluctant to bring in outside voices, and groups have felt excluded, despite their EU expertise, according to Jeremy Richardson. 


\section{'Managing' decision-making consultations}

Elections inherently give policy-makers only a crude and infrequent idea of public opinion. Parties must aggregate issues together into programmes and manifestos. Citizens can only cast a single vote, with no capacity to indicate which issues or policy commitment counts most with them. Nor can they express the different strength of their preferences on multiple issues. So even politicians with a clear manifesto commitment to implement have just a direction of travel, not a detailed route map for getting anywhere that works.

Public consultation processes (some linked to legislation or executive orders) generate huge volumes of very specific information about how and why different interests are affected by proposed policy changes, which will bear costs and which see benefits in them. Often the detailed information needed for effective policy implementation rests with trade associations, firms, trade unions, professions, NGOs, sub-national governments, or academia rather than in Whitehall. Hence in any policy area there will either be a 'policy community' that is strongly networked, regularly influential and perhaps closed to outsider groups. Alternatively there may be a looser 'policy network', linking the main groups that regularly comment on policy issues, but with more weakly tied or changeable sets of participants.

A well-organised civil society may seem to leave Whitehall and ministers in a weak position, and in the past some political scientists rather fancifully described a 'hollow crown' that has resulted in the UK. However, ministers and civil servants do not assign equal weight to all actors in networks, but instead demand 'responsible' behaviours from those to whom they will listen, such as think tanks, business lobbies, professions or expert academics. 'Insider' groups have the ear of policy-makers, while more strident, public and 'extreme' voices are routinely discounted.

Finally, sophisticated opinion polling now allows both politicians and the public to regularly learn how different types of citizen feel about issues - so the policy influence of public opinion as a whole has improved and magnified. A lot of media and social media coverage and commentary also ensures that policy-makers continuously 'get the message' about which bits of their proposals are popular and with whom.

\section{Corporate power in the interest group process}

Yet is the apparent diversity and pluralism of the consultation process just a misleading façade? Vladimir Lenin famously argued that the liberal democratic state was 'tied by a thousand threads' into doing things that owners of capital want. And a concern about the 'privileged position of business' in dealing with government extends widely amongst liberal authors too, such as Charles Lindblom. Since businesses generate economic growth and taxes, they have special salience in making demands on politicians and officials. And as the journalist Robert Peston argued:

'The wealthy will [always] find a way to buy political power - whether through the direct sponsorship of politicians and parties, or through the acquisition of media businesses, or through the financing of think tanks. The voices of the super-wealthy are heard by politicians well above the babble of the crowd.... We are more vulnerable than perhaps we have been since the nineteenth century to the advent of rule by an unelected oligarchy' (p.346). 
In a discussion for Democratic Audit, David Beetham drew attention to how dominant financial corporate sectors in the UK economy first caused the 2008 economic crash by forcing through rash financial deregulation. But these same interests were then differentially rescued by unprecedented state bailouts by the biggest banks. And to stop a wider decline, 'quantitative easing' by the Bank of England propped up the asset values of the wealthiest groups in society. Via transfer pricing, debt loading and shifting domicile the largest global companies have also effectively evaded corporation taxes and undermined the UK fiscal regime. Public disquiet and 'tax-shaming' mobilisations by online activists have dented this regime (for example, a consumer boycott forced Starbucks into 'voluntarily' paying nominal amounts of UK corporation tax), and forced a rethink of previous pro-multinational tax policies across the OECD.

\section{Competition between 'advocacy coalitions'}

A more benign view of changes in the interest group process is given by the 'advocacy coalition framework' (ACF). This modern pluralist view argues that the key influences on public policies now are cognitive ones, turning on empirical evidence, research and cognitions. Old-style, 'big battalion' groups - like big corporations, media barons and mass ranks of trade unions - sought influence on the basis that they could mobilise adverse votes at the ballot box or unfavourable coverage by media commentators. But most policylevel influence now comes from a different process of cognitive competition where rational arguments and evidence chiefly sway policy-makers, not political self-interest alone.

Nor are the battles that matter fought any longer by single interest groups, but rather by competing 'advocacy coalitions' that bring together diverse clusters or networks of groups aligned on each side of the policy debate. For example, on tobacco policy a succession of nudge interventions by government followed up periodically by regulatory restrictions and new legislation have progressively strengthened the disincentives for smoking and curtailed 'passive smoking' in the UK - and Figure 2 shows impacts in terms of falls in the number of smokers. The apparently ascendant coalition here includes anti-smoking charities, the medical professions, NHS authorities, the health department in Whitehall, progressive local authorities who forced the pace of implementation, many non-smokers (especially those adversely affected by 'passive smoking'), and so on.

The coalition fighting a rearguard action against smoking regulation includes of course the tobacco corporations front and centre, plus some other aligned businesses, pro-'freedom' or libertarian think tanks, Tories opposing a 'nanny state', and a diminishing minority of stillenthusiastic smokers.

Yet has the progress achieved in reducing smoking incidence over recent decades been fast and furious (as defenders of the UK's policy apparatus might say), or slow and often stalled? How you assess the scale and speed of these changes will shape how effectively you think cognitive competition changes the dynamics of group competition. 
Figure 2: The proportion of men and women smoking in Great Britain, 2000-17

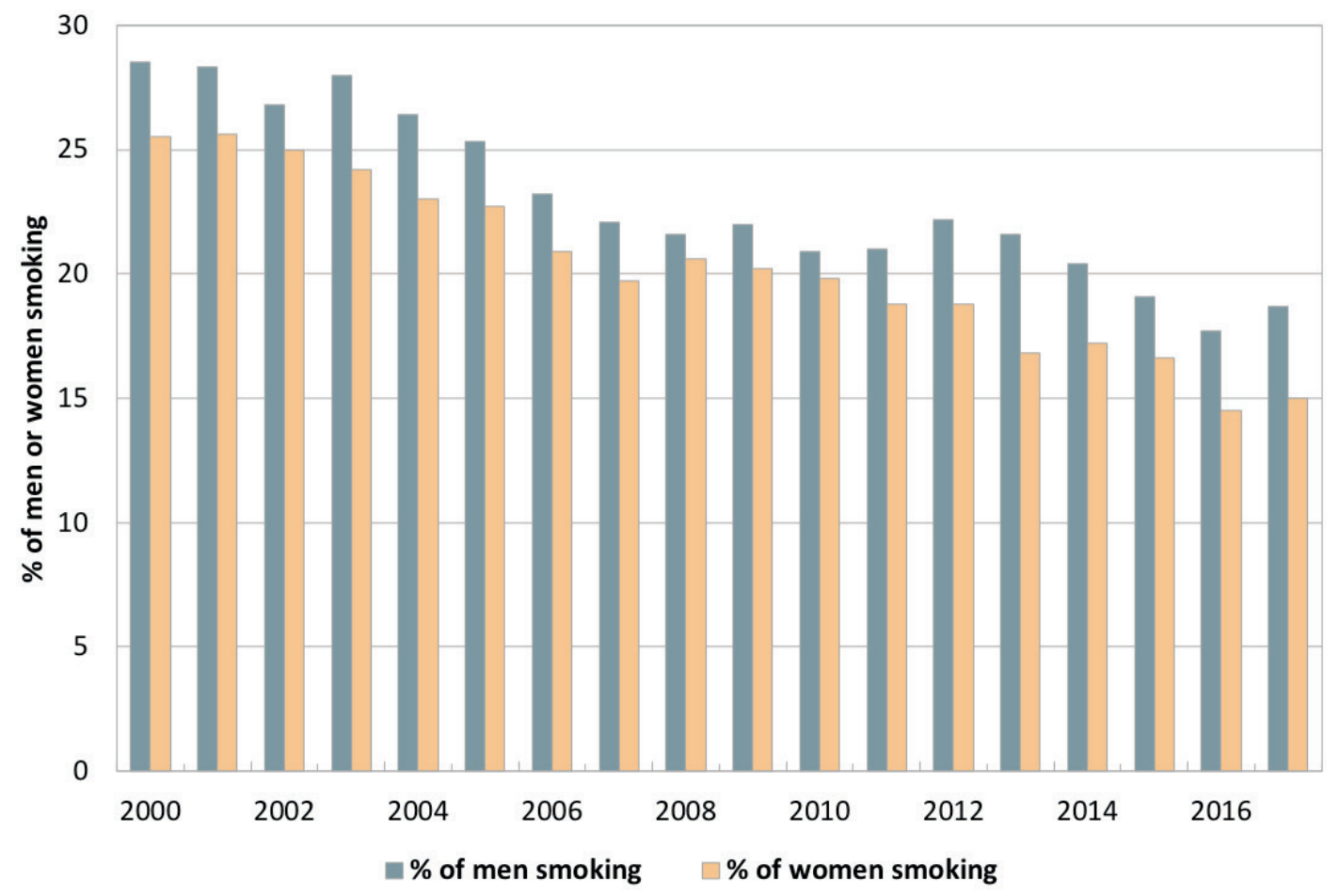

Source: Office of National Statistics Dataset, 2018.

\section{Conclusions}

Nobody now claims that the UK's interest group process is an equitable one (a position wrongly attributed to pluralists by their critics). Even common sense requires that we recognise there are big and powerful lobbies, medium influence groups and 'no hopers' battling against a hostile consensus. Democracy requires that each interest be able to effectively voice their case, and have it heard by policy-makers on its merits, so that the group can in some way shape the things that matter most to them. On the whole, the first (voice) criterion is now easily met in Britain. But achieving any form of balanced, deliberative consideration of interests by policy-makers remains an uphill struggle. Business dominance is perhaps reduced by restrictions on lobbying and extra transparency from social media. But it is still strong, despite some shifts towards cognitive competition over policy solutions and towards more deliberative and evidence-based policy-making.

Patrick Dunleavy is Professor of Political Science and Public Policy at the LSE and coDirector of Democratic Audit there. He is also Centenary Professor in the Institute for Governance and Policy Analysis (IGPA), University of Canberra. 


\section{The media system}

The growth of 'semi-democracies' across the world, where elections are held but are rigged by state power-holders, has brought into ever-sharper focus how much a country's media system conditions the quality of its democracy. Free elections without some form of media diversity and balance clearly cannot hope to deliver effective liberal democracy. Ros Taylor and the Democratic Audit team look at how well the UK's media system operates to support or damage democratic politics, and to ensure a full and effective representation of citizens' political views and interests.

\section{What does liberal democracy require of a media system?}

The media system should be diverse and pluralistic, including different media types, operating under varied systems of regulation, designed to foster free competition for audiences and attention, and a strong accountability of media producers to citizens and public opinion.

$\downarrow$ Taken as a whole, the regulatory set-up should guard against the distortions of competition introduced by media monopolies or oligopolies (dominance of information/content 'markets' by two or three owners or firms), and against any state direction of the media.

A free press is a key part of media pluralism - that is, privately owned newspapers, with free entry by competitors and only normal forms of business regulation (those common to any industry) by government and the law.

Because of network effects, state control of bandwidth, and the salience of TV/radio for citizens' political information, a degree of 'special' regulation of broadcasters to ensure bipartisan or neutral coverage and balance is desirable, especially in election campaign periods. However, regulation of broadcasters must always be handled at arm's length from control by politicians or state officials, by an impartial quasi-nongovernmental organisation (quango) with a diverse board and professional staffs.

Where government funds a state broadcaster (like the BBC), this should also be set up at arm's length, and with a quango governance structure. Government ministers and top civil servants should avoid forms of intervention that might seem 
to compromise the state broadcaster's independence in generating political, public policy or other news and commentary.

Journalistic professionalism is an important component of a healthy media system, and the internalisation of respect for the public interest and operation of a 'reputational economy' within the profession provide important safeguards against excesses, and an incentive for innovation. Systems that strengthen occupational self-regulation within the press are valuable.

The overall media system should provide citizens with political information, evidence and commentary about public policy choices that are easy to access, at no or low cost. The system should operate as transparently as possible, so that truthful/factual content predominates, it quickly 'drives out' incorrect content and 'fake news', and that 'passing off' and other lapses are minimised and rapidly counteracted.

People are entitled to published corrections and effective redress against any reporting that is unfair, incorrect or invades personal and family privacy. Citizens are entitled to expect that media organisations will respect all laws applying to them, and will not be able to exploit their power to deter investigations or prosecutions by the police or prosecutors.

Public interest defences should be available to journalists commenting on possible political, state and corporate wrongdoing, and media organisations should enjoy some legal and judicial protection against attempts to harass, intimidate or penalise them by large and powerful corporations, or by the state.

At election times especially, the media system should inform the electorate accurately about the competing party manifestos and campaigns, and encourage citizens' democratic participation.

The UK has long maintained one of the best developed systems for media pluralism amongst liberal democracies, centring on five components:

(i) A free press, one that is privately owned and regulated only by normal business regulations and civil and criminal law provisions. The biggest UK newspapers are highly national in their readership and coverage. They characteristically adopt strong political alignments to one party or another. A voluntary self-regulation scheme has provided only a weak code of conduct and system of redress in the event of mistakes in reporting or commentary.

(ii) A publicly owned broadcaster (the BBC), operated by a quasi-non-governmental agency (quango), at arm's length from any political control by the state or politicians. It is regulated by another arm's length quango, Ofcom, so as to be politically impartial in its coverage, according space to different parties and viewpoints.

(iii) A few private sector broadcasters whose political coverage is regulated by the same set of rules to be politically impartial - which are also set and enforced by Ofcom, insulated from control by politicians, the state and from the broadcasters themselves. 
(iv) Strongly developed journalistic professionalism, with common standards of reporting accuracy, and much looser agreement on fairness in commentary and respect for privacy, shared across (almost) the whole occupational group. But breaches are enforced only informally by weak social sanctions, such as disapproval or reputational damage for offenders within the profession.

(v) Social media, which are an increasingly salient aspect of the media system, and resemble the free press in being unregulated beyond normal legal provisions. The biggest online sites and associated social media are journalistically produced by newspapers, and generally operate on the same lines, although with less political colouration of news priorities. However, much politically relevant content is also generated by a wide range of non-government organisations (NGOs), pressure groups and individuals, many of whom are strongly politically aligned and may not feel bound by journalistic standards. (See Chapter $\mathbf{3 . 4}$ for a detailed discussion of social media.)

\section{Recent developments}

In recent years, the UK's media landscape has undergone enormous transformation. Not only has news consumption shifted online, but the growth in digital social media has enabled people to originate, find and share information in ways that challenge the traditional hegemony of state-funded broadcasters and the national press.

The biggest source of concern about the democratic qualities of the UK's media system has been that most of the press perennially back the Conservative Party (in very forceful ways in most cases). Far fewer papers normally back Labour, and the Liberal Democrats receive only episodic support from smaller papers. Once predicted to become just another depoliticised operation of conglomerate corporations, in fact newspapers are still run in a hands-on, 'press baron' fashion by powerful companies or media magnates (like Rupert Murdoch and the Barclay brothers). Figure 1 shows that the fiercely anti-Labour and proBrexit Sun is by far the biggest newspaper, and Rupert Murdoch also owns the Times/ Sunday Times. The Daily Mail, Daily Express and Daily Telegraph complete the Tory press hegemony. The Labour-backing Trinity Group newspapers (owning the Daily Mirror, Daily Record, and The People) have smaller readerships, as does the Guardian. Some papers also take a neutral or more varied political line. 
Figure 1: The percentage of UK respondents who used different TV, radio and print news sources in 2017 - and the political affiliations of these sources

\begin{tabular}{|c|c|c|c|}
\hline Source & Political stance & $\begin{array}{l}\% \text { used } \\
\text { in last } 3 \\
\text { days }\end{array}$ & $\begin{array}{l}\% \text { used } \\
\text { in last } \\
\text { week }\end{array}$ \\
\hline BBC News (TV \& radio) & Regulated non-partisan & 53 & 64 \\
\hline ITV News & Regulated non-partisan & 20 & 33 \\
\hline Sky News & Regulated non-partisan & 14 & 21 \\
\hline Sun (\& Sunday Sun) & Conservative, Brexiteer & 7 & 15 \\
\hline Daily Mail (\& Sunday) & Conservative, Brexiteer* & 8 & 13 \\
\hline Metro (free) & Non-political & 6 & 11 \\
\hline Regional or local newspapers & Varied & 4 & 11 \\
\hline Daily Mirror (SM, Daily Record) & Labour, EU pragmatic & 6 & 10 \\
\hline Channel 4 News & Regulated non-partisan & 4 & 10 \\
\hline Commercial radio news & Regulated non-partisan & 7 & 10 \\
\hline Times/Sunday Times & Conservative, EU pragmatic & 3 & 7 \\
\hline Guardian/ Observer & Labour, Remainer & 2 & 5 \\
\hline London Evening Standard (free) & Conservative, Remainer & 2 & 4 \\
\hline Daily Telegraph (\& Sunday) & Conservative, Brexiteer & 2 & 4 \\
\hline 'I’ (newspaper) & Independent, Remainer & 2 & 4 \\
\hline CNN & Regulated non-partisan & 1 & 4 \\
\hline Daily Express (\& Sunday) & Conservative, Brexiteer & 1 & 2 \\
\hline \multirow{4}{*}{ Political orientation of source } & Regulated non-partisan & 99 & 142 \\
\hline & Conservative & 24 & 47 \\
\hline & Labour & 8 & 15 \\
\hline & Independent, non-political press & 8 & 15 \\
\hline \multirow{3}{*}{ Brexit orientation of source } & Brexiteer & 18 & 34 \\
\hline & Neutral or EU pragmatic & 105 & 153 \\
\hline & Remainer & 4 & 9 \\
\hline
\end{tabular}

Source: Data from Reuters Institute Digital News Report 2018 (Express from full survey data supplied). Classifications of political orientations by the authors.

Note: Percentages sum to more than $100 \%$ because people use multiple media sources. *The Daily Mail was strongly pro-Brexit, but the Mail on Sunday supported Remain. 
However, Figure 1 also shows that in terms of media exposure the non-partisan broadcast news media have maintained far more reach and regular use than print newspapers. In modern times a trio of TV news outlets (BBC, ITV and Sky News) plus radio have provided much of people's political information. All broadcasters operate under political neutrality rules that apply with special force during election campaigns. They must achieve a bipartisan balancing of Conservative and Labour issues and viewpoints (given their historic dominance in shaping general election voting) plus the broadly proportional representation of other parties - for example, giving the SNP in Scotland equal prominence. Optimists about the media system would point out that in Figure 1 four times as many people have used non-partisan media than have read Conservative-aligned newspapers. Similarly, more than five times as many people have used sources that take a neutral or pragmatic view of Brexit than have used strongly pro-Brexit sources. Figure 1 also shows that most people use multiple media sources and thus are exposed to a mix of partisan and non-partisan coverage of issues and politics.

However, newspaper-run websites now provide major sources of revenue for the press, and they compete for online attention with the broadcasters' websites and online-only publications. Figure 2 shows that the papers' online readership produces a greater balancing of political alignments in the digital world. During the 2015 and 2017 election campaigns Labour enjoyed the backing of the Guardian website, which has a much bigger reach than its print version. The Daily Mirror is also prominent. On the Tory side the Daily Mail is the leading online title, along with the Telegraph.

Figure 2: The online monthly readership of UK newspaper websites (in 2017)

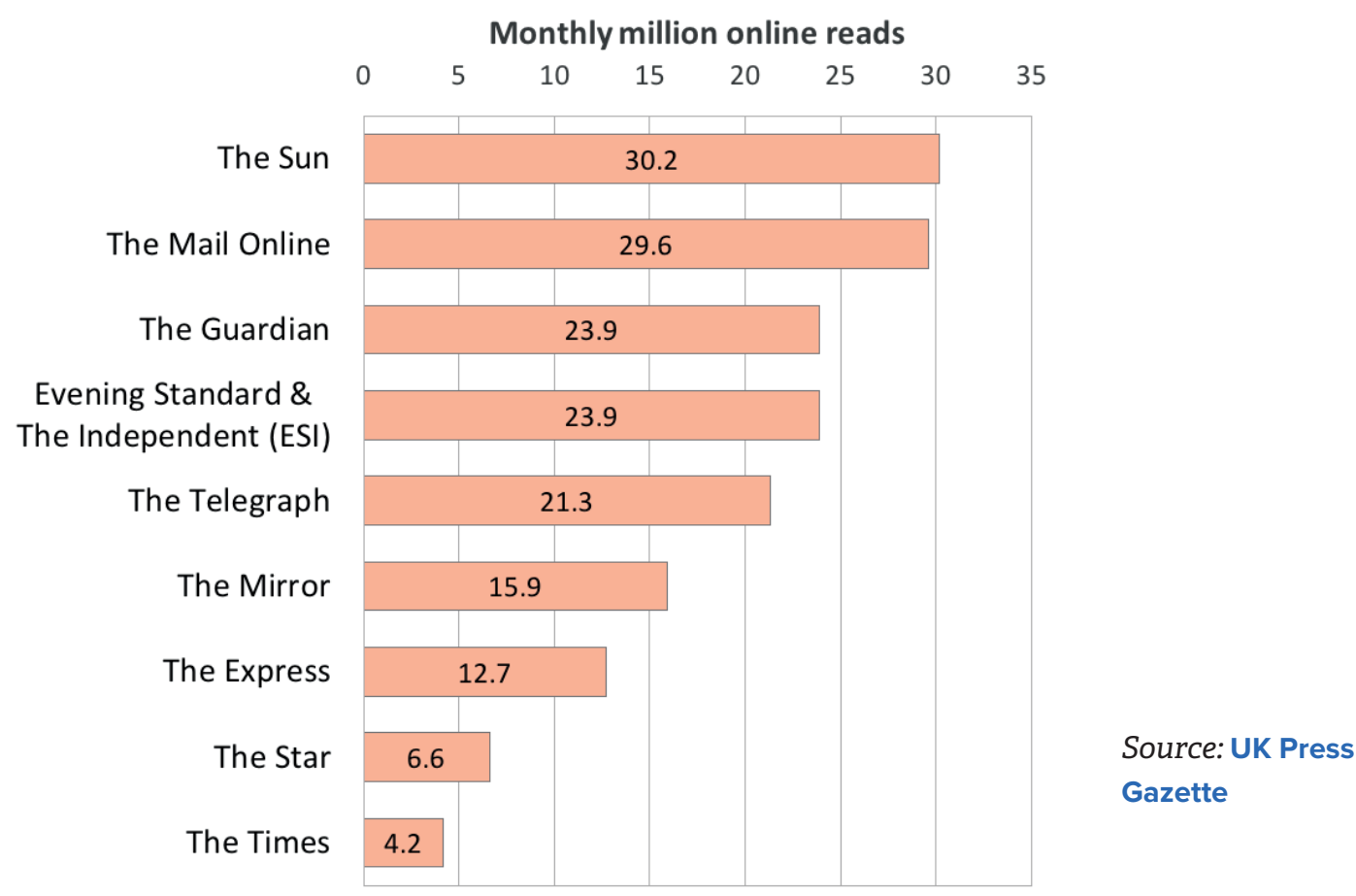


These modifying factors perhaps have begun to blunt the 'power of the press' compared with (say) the 1992 general election, when Murdoch's leading title boasted 'It was the Sun wot won it' for John Major. In 2017, the Sun's election day 'Cor-Bin' front page was no less strident in denouncing Jeremy Corbyn. On the day before polling, the Daily Mail devoted 13 pages to anti-Corbyn and anti-Labour stories and commentary, with the cover headline 'Apologists for Terror'). The levels of political bias exhibited can also be strikingly unconstrained, verging into 'fake news' generation, with, for example, the front pages of the Sun and Daily Mail both explicitly linking top opposition politicians to terrorist threats.

Yet optimists about the media system point out that Corbyn's Labour surged in popularity during the campaign, and forced a hung parliament, despite facing a wall of Tory press criticism. Perhaps, then, media diversity is working after all, allowing voters to form their own opinions from a range of different sources?

\section{Strengths, Weaknesses, Opportunities, Threats (SWOT) analysis}

\section{Current strengths}

Figures 1 and 2 demonstrate that the UK's media system remains essentially pluralistic when taken as a whole, especially in the complementary nature of a free press offset by bipartisan regulated broadcasting.
The growth of satellite and online TV channels, and rapid increases in the numbers of specialised or paid-for TV channels (many catering for niche interests) has reduced the ways in which TV presents a common news agenda to all citizens. Yet the BBC, ITV, Channel 4 and Sky News still compete very effectively for news and politics audiences (Figure 1). Although its audience is ageing somewhat, the BBC's broadcast news coverage continues to reach two-thirds of the public each week.

\section{Current weaknesses}

The print versions of the leading national newspapers remain wedded to highly partisan approaches to covering UK politics and elections. Cross-ownership of titles and broadcasting by powerful and committed corporate leaders actively trying to sway elections and policy decisions (like Rupert Murdoch) perennially distorts political power away from political equality. Traditional forms of joint agenda-setting by journalists ('wolf pack' questioning on top issues) and new developments (for example, press preview programmes on 24-hour TV and press front pages on broadcaster websites) mean that press distortions can drag public service broadcasters into line with a press-led agenda.

\section{Press coverage of the 2016 EU referendum} campaign was frequently hyper-partisan, disingenuous or actively misleading (as in claims that Turkey was poised to join the EU). If and when such claims were ever corrected at a media regulator's request, this happened only after readers had voted. 


\section{Current strengths}

The mainstream press has experimented with subscription models that offer an alternative to paywalls, such as voluntary subscriptions or one-off donations and crowd-funded journalism.

\section{Current weaknesses}

The public's reluctance to pay for news, both online and offline, as well as declining advertising revenues and insurgent start-ups, represent an existential threat to established press brands and perhaps other media. The local press is also in decline, with far fewer reporters. Those who remain are sometimes based outside their 'beat' and discouraged from original reporting for reasons of time and cost.

Several new versions of self-regulation have emerged, with Impress and Ipso offering different models (see below). The closure of the News of the World over its toxic phonehacking culture still looms large in editors' and journalists' consciousness.

The Freedom of Information Act, a key right for citizens that is also a valuable tool for journalists, has survived repeated threats due to Whitehall cost-cutting and politicians' hostility to it.

Parliamentary reporting has adapted to the live blog format, arguably providing a more detailed and real-time account of proceedings than the legacy print media did.
The newspaper industry has failed to reach consensus on press regulation after the hacking scandal and Leveson report, including on the chilling effect of section 40 of Crime and Courts Act (see below). Complaints mechanisms are often weak and unclear, especially among new entrants.

Court injunctions to force the press to respect people's privacy are the preserve of the very wealthy, though are now declining in numbers. Ordinary citizens typically find it hard to achieve redress or corrections for mistakes from newspapers.

Coverage of Welsh politics is especially inadequate. The nation lacks a powerful home-grown media and the Welsh Assembly has considered appointing its own team of journalists to report proceedings. Like local authority-run newspapers, this is a problematic development.

\section{Current opportunities}

Libel cases have fallen since the Defamation Act 2013 simplified the public interest defence. If the trend is maintained, this may enable more adventurous investigatory reporting in future.

\section{Current threats}

Mainstream media and journalists are increasingly distrusted by the public, particularly on the left, for their perceived biases and remoteness from 'ordinary people'. 


\section{Current opportunities}

Citizens have mobilised on social media to counteract newspaper partisan or commentary excesses - for example, Stop Funding Hate's campaign to shame big advertisers into boycotting newspapers accused of anti-Islam coverage and stirring up racial hatred. As online sources grow more salient, so a somewhat less partisan style of political journalism may take root. Crowd-funded initiatives like WikiTribune may have the potential to make the ownership and administration of media outlets more transparent and accountable to their readers.

Recognising the dearth of local news reporting, some efforts are being made to fund and train reporters (see below).

Hyperlocal news models continue to evolve, with the ease of making micropayments offering the possibility of an (albeit unpredictable) revenue stream (see Chapter 3.4 on social media).

\section{Current threats}

Both 'alt-left' and 'alt-right' media outlets, run directly by political interest groups seeking to manipulate public debates, have already penetrated the UK market. They have often used 'data-industrial complex' methods to target sets of swing citizens, and paid-for Facebook and Twitter 'news' generation to evade journalistic controls or scrutiny. The alt-left (for example, the Canary and Evolve Politics) claimed extensive influence in the 2017 general election, while the alt-right (and possibly Russian intelligence) seems to have helped sway the EU referendum campaign towards 'Leave'.

Official proposals for a modernised Espionage Act could threaten whistleblowers and introduce a further chilling effect to journalists' ability to pursue stories relating to the 'secret state'.

The declining sales of local newspapers, and the closure of many titles, plus the relative weakness of regional and local broadcasting within the BBC and ITV, have all meant that journalistic coverage of local politics has drastically fallen away. Court reporting is also in steep decline.

\section{The BBC and Sky}

The regulated TV broadcasters (and in the BBC's case, state-funded too) have been a key part of the UK's media system since the BBC was set up in the 1920s. Their role enjoys a wide amount of cross-party consensus, but the Tory press has constantly accused the BBC of having a 'left-wing' and liberal causes bias. Conversely, in 2015-17, when Jeremy Corbyn's Labour leadership was controversial, some 'alt-left' outlets attacked the BBC (and in particular its political editor, Laura Kuenssberg) for bias against him. The BBC is now externally regulated by Ofcom, putting it on a par with other regulated broadcasters, instead of the previous exceptional situation where the BBC Trust was both 'judge and jury' on major complaints. The BBC's once very extensive online web presence has also been greatly cut back to focus on news and programme-specific sites, chiefly as a result of commercial rivals complaining to Ofcom that it was 'crowding out' their own web operations.

A Conservative government green paper in 2015 raised the possibility of cutting or reforming the BBC's licence fee (a disliked tax on TVs) and cutting back the corporation's 
remit to focus on news. However, the charter renewal of January 2017 guaranteed the licence fee's survival for at least 11 years, with inflation-linked increases until early 2022. A new BBC Board - no more than half of whose members are government appointees - was put in place to manage the Corporation. The National Audit Office will now play a role in scrutinising BBC spending.

The BBC also undertook to serve ethnic minority and regional audiences better. The BBC Trust previously found that audiences in the devolved regions felt the corporation needed to do more to hold their politicians to account, particularly in Wales, where Cardiff University's 2016 Welsh Election Study identified a 'democratic deficit' in media. In Scotland SNP supporters have regularly argued that the BBC is pro-union and called for a separate Scottish Broadcasting Corporation to be set up. Across the UK, the reach of BBC services is falling as its radio and TV audience ages.

The Brexit referendum campaign represented a major challenge for all the UK media, but particularly so for the BBC's public service remit and due impartiality. The subject matter was complex and the public was poorly informed about the history and functions of the EU. The BBC's referendum guidelines sought to give 'due weight' and prominence to all the main strands of argument and to all the main parties, rather than being an overly simplistic 'seesaw' approach to impartiality - the latter critiqued by Jay Rosen as 'views from nowhere'. Despite these efforts, the BBC was criticised for inadequate scrutiny of campaign claims on both sides and faced particular opprobrium from Leave-supporting politicians and newspapers. After the vote criticism continued from both Leavers and Remainers.

At the height of the News of the World phone hacking scandal, the Murdoch-run 21st Century Fox (the ultimate owner of the Sun and the News of the World) withdrew a bid to assume full control of Sky that had previously seemed likely to succeed. After an interregnum, the bid was renewed and Ofcom was lobbied to block it on the grounds that Murdoch's companies failed a 'fit and proper' persons test. Ofcom did not agree and let it continue, but the issue was referred by the minister to the Competition and Mergers Authority. Their initial findings in January 2018 said that the merger was not in the public interest because of media plurality concerns. In July 2018, 21st Century Fox successfully bid for Sky, on condition that Sky News was divested to a buyer that will fund it for a decade and guarantee its independence.

This bidding war also reflected a new and salient challenge to the established broadcasters (and Hollywood film studios) posed by new media players Amazon, Netflix and some similar competitors focusing on paid-for, on-demand streaming of drama and entertainment only, paralleling the earlier growth of sports and specialist channels. As millions of consumers migrate to these services, so the audiences for regular bipartisan TV news may be eroded - because fewer people are following TV services offering a mix of services with regular slots for news.

\section{Newspaper closures and online paywalls}

For the 'free press' across the UK, the viability of newspaper titles is crucial. With sales and advertising revenue falling, the Independent newspaper ceased all print editions to 
become online only, and subsequently reported a return to profit. The Times and Financial Times continued to maintain online paywalls to fund their journalism, with the Telegraph also erecting a partial paywall. The London Evening Standard became a free paper in 2009 , maintaining its circulation. However, only $3 \%$ of Britons have an online news subscription, one of the lowest percentages across the European Union. At Murdoch's insistence, The Sun experimented with a paywall in 2013, but abandoned it two years later as its online readership numbers fell. A majority of readers seem unwilling to pay for online news when it is freely available elsewhere. However, the Guardian reports 500,000 regular paying supporters and a further 300,000 one-off contributors.

Regional papers in big cities outside London, and local publications across the country, also experienced a drop of 12\% in digital and print revenues in 2015-16. Across the UK 198 local papers closed in 2005-16, plus 40 more in 2017. Falling advertising revenues have been the principal driver of local journalism's decline, but not the only one. More people have been renting privately and moving between local areas. The sociologist Anthony Giddens argued that social life has become 'dis-embedded' from the local level, so that 'we cannot take the existence of local journalism for granted'. The decline in local reporting was exemplified in tragic fashion by the failure of west London's press to pick up on the repeatedly expressed concerns of the Grenfell Tower residents on the Grenfell Action Group blog about the safety of their building, before it burnt down, killing 72 people in June 2017.

Some efforts are being made to reinvigorate the sector. The BBC has earmarked £8m for 'local democracy reporters' from selected news services, giving them training and access to BBC video and audio. In addition, the local press decline has been a key catalyst for a growth of citizen-driven hyperlocal sites (see Chapter 3.4).

\section{Media ownership, partisanship and transparency}

A diversity of media ownership has historically been seen as important because of the strong political orientation of the national newspaper titles. But in addition, owning newspapers has often helped different capitalist interests to advance their own interests in regulatory matters and other public policy concerns, especially where press titles and broadcast channels are owned by the same mogul or firm. Elected politicians may want to keep powerful media owners onside and so give them the benefit of the doubt in regulatory decisions.

Ownership of the major newspapers has long been divided among a few large companies, with the American-owned News Corp, publisher of the Sun and the Times/Sunday Times, as the dominant player. These, along with the Daily Mail (DMG Media), the Daily Express (bought by Trinity Mirror in 2018) and the Telegraph Media Group, continue to dominate right-leaning coverage, while the Mirror, the Guardian and the Independent occupy the left or centre. Pearson sold the Financial Times to the Japanese company Nikkei in 2015. A Saudi investor, Sultan Muhammad Abuljadayel, took a stake of between 25\% and 50\% in the Independent's holding company in 2017, causing concern among some of its journalists, although they were assured its editorial independence would remain intact. 
However, online media has inflicted considerable disruption on the newspaper-dominated press model. Digital entrants have used social media to disseminate free news and opinion. Some originate in the US (BuzzFeed, the Huffington Post, Vice), others are funded by the Russian state (Russia Today and the Edinburgh-based Sputnik). A number of hyper-partisan low-cost start-ups - such as Evolve Politics and the Canary, a free-to-access site funded by advertising and voluntary subscriptions - have generated their traffic via Facebook. These last, which backed the Labour leader Jeremy Corbyn unreservedly, enjoyed particular success during the 2017 general election campaign. Their online reach among younger voters during that campaign may have exceeded that of the established mainstream press.

New entrants are overwhelmingly digital, but in print media the free Metro and small-scale print publications such as the anti-Brexit weekly the New European (owned by Archant Media) - have also meant that UK media are more pluralistic than ever before. Some new players are not transparent about their ownership and do not always choose to join a regulator. Neither Sputnik nor Breitbart provide any channel for readers to make a complaint about their reporting, apart from an online contact form on the Sputnik page, and neither are members of a press regulation body. Social media also presents a new set of challenges to democratic debate (see Chapter 3.4).

Journalists have been gloomy about the decline of paid-for news contents and its adverse implications for the health of media outlets and the ability of the press to report freely. Freedom House identified 'varied ways in which pressure can be placed on the flow of objective information and the ability of platforms to operate freely and without fear of repercussions'. They rated the UK's media environment as 'free' in 2017, giving it an overall score of 25 (where 0 denotes the most free and 100 the least). This represents a four-point worsening in the UK's score since 2013. Although Freedom House considers the UK's press 'largely open', significant concerns about regulation and government surveillance are unresolved.

\section{Press regulation and the Crime and Courts Act}

Poor or inaccurate media reporting (especially by the press) may generate a great deal of misery for the people involved. UK newspapers maintained for many years a very weak apparatus of 'self-regulation', which collapsed in the wake of a major scandal about reporters at the News of the World, Daily Mirror and other tabloid titles 'hacking' the phones of celebrities and politicians so as to uncover aspects of their private lives. This was always a criminal activity, but Scotland Yard proved strangely reluctant to act until long after the large scale of scandal became apparent. In 2014, the BBC's sensationalist live reporting of the search of singer Cliff Richard's home as part of an investigation into allegations of sexual offences, featuring helicopter shots of a police raid, was apparently based on police leaks. With the case later dismissed, it proved controversial, and the Corporation eventually had sizeable damages and legal costs awarded against it for invading Richard's privacy, in a court judgment that some critics argued would constrain future press freedom.

The phone-hacking scandal produced a long-delayed Inquiry into the Culture, Practices and Ethics of the Press chaired by Lord Leveson. It deemed the previous Press Complaints Commission 'not fit for purpose' and it was dissolved. But Leveson's call for 
an independent, self-regulatory body to create and uphold a new standards code for the media failed to get press cooperation. The only government-created (but independently appointed) Press Recognition Panel (PRP) is Impress, which regulates over 100 small, chiefly local and digital publications. Most national newspapers have joined the Independent Press Standards Organisation (Ipso). However, the Financial Times and the Guardian chose to set up their own internal mechanisms for handling complaints, citing worries about Ipso's independence and the royal charter model that underpins it. The charter is not a statute but is drafted and approved by the Privy Council, which its critics argue amounts to 'unacceptable political involvement' in press regulation.

To try and make publishers join a PRP-approved regulator, section 40 of the coalition government's Crime and Courts Act 2013 gave those that have done so the opportunity to settle libel action through a low-cost arbitration scheme. If they did not, they may be liable for the claimant's costs in libel, privacy or harassment cases. The vast majority of the press have vociferously opposed the implementation of section 40, with the Financial Times opening its objections by claiming that the press landscape had been 'utterly transformed' since the publication of the Leveson report. Index on Censorship warned that section 40 'protects the rich and powerful and is a gift to the corrupt and conniving to silence investigative journalists - particularly media outfits that don't have very deep pockets'. In March 2018 the responsible minister announced that section 40 would be repealed, and the previously proposed second part of the Levenson inquiry scrapped - leaving the shape, let alone the effectiveness, of any future press regulation or self-regulation unclear.

\section{Libel law and 'gag' orders}

For decades the English law of libel has provided for potentially large damages against anyone publishing statements likely to lower the reputation of the claimant in the eyes of reasonable people, even if the statements were true. Papers also had to prove that 'defamatory' statements were not maliciously motivated. The Defamation Act 2013 simplified the so-called 'Reynolds defence' against libel by codifying it more simply: if a statement is in the public interest and the writer reasonably believes it to be so, it enjoys protection. In addition, a libel claimant must prove the statement caused 'serious' harm. English PEN and Index on Censorship both welcomed the overhaul: 'England's notorious libel laws [have been] changed in favour of free speech', said the latter. The number of defamation cases fell to around 60 in the three years 2014-16. A growing proportion of these related to social media postings by private individuals.

English law also allows for 'gag' injunctions preventing publication of details (like names) if the subject can claim their privacy would be damaged. In recent years these have declined greatly, because such information can easily be published by third parties online, and court proceedings made public, thus undermining the very purpose of the action. The privacy injunction remains a tool of the rich: 'With average legal fees of $£ 400$ an hour, the first court hearing would cost up to $£ 100,000$,' reported the Guardian in 2016. For almost all citizens, pre-emptive action against breaches of privacy is out of the question, and post-hoc privacy actions are likewise impossible. Self-regulation and effective means of redress therefore take on an even greater importance. 


\section{Leaking of government secrets and a proposed Espionage Act}

The UK government operates a system (called D notices) where the responsible minister can exceptionally bar papers or broadcasters from running items that would endanger a clear national interest (for example, publishing the names of UK espionage agents). UK journalists have been vigilant in keeping such cases to an absolute minimum. However, other developments have changed the picture a lot.

In 2013, the American IT contractor Edward Snowden passed large amounts of classified material from the US National Security Agency (NSA) to the Guardian and Washington Post which revealed details of government surveillance programmes, also involving GCHQ (the UK's electronic surveillance agency). GCHQ requested the Guardian to handover its copy of the material. Instead, warned that the security services were considering taking legal action to halt its reporting, the paper destroyed the hard drives and memory chips with cutting tools at their offices. This was 'a largely symbolic act' the paper said, because the same files were stored in other jurisdictions.

As a result, the Law Commission, a normally neutral, expert legal body, undertook a review of the Official Secrets Act, and recommended its replacement with a modernised Espionage Act in 2016. The proposals immediately created fears that they would criminalise receiving and handling any data that the government deems damaging to national security, even if editors and journalists were merely examining leaked material. The influential Open Rights Group described the new provisions as a 'full-frontal attack on journalism.... The intention is to stop the public from ever knowing that any secret agency has ever broken the law.' However, the Commission's 'public consultation' was badly mishandled, and its publicity was even worse. The proposals were sent back for more work, initially planned for autumn 2017 and then postponed to September 2018. The Commission insists on its website that under its proposals:

'An offence is only committed if the defendant "knew or had reasonable grounds to believe his or her conduct was capable of benefitting a foreign power and intended or was reckless as to whether his or her conduct would prejudice the safety or interests of the state". Currently someone can commit an offence under the Official Secrets Act 1911 even if he or she thought their conduct was in the interests of the UK.'

\section{Re-establishing trust}

While trust in the BBC's ability to deliver accurate and reliable news remains high (70\%), trust in journalists in the UK overall remains much lower than in most of the EU and USA. It is lower still among under-35s and those who describe themselves as left-wing. Among journalists themselves, most say owners, advertising and profit considerations have little influence over their work. A quarter of them believe that it is sometimes justifiable to publish unverified information.

However, fact-checking has become an increasingly common practice online, pioneered by the charity FullFact, and later adopted by the BBC, Channel 4 and Guardian. Google's 
Digital News Initiative is currently looking at ways to automate parts of the process. Mindful of how Donald Trump's presidency came about and has developed, the media industry is beginning to grapple with the question of how to report untrue or contested statements made by top politicians.

\section{Conclusions}

The media system is changing fast, and it is often easy to lament all change as a decline from a past golden age, and to resent 'new goods' that are having disruptive effects. Optimists, on the other hand, argue that the choice and variety of news information available to Britons have never been greater and that press and broadcasters are free from censorship or direct government interference.

Pessimists see a largely unreconstructed national press, wedded to truth-bending, high intensity partisanship, with unregulated power concentrated in the hands of a few press barons (often pushing their corporate agendas as well business interest), and a wider profession resistant to any meaningful professionalism or effective self-policing of journalistic practices. In the wings, UK government and official sources have proposed restrictive laws that would greatly inhibit journalistic enterprise and ability to investigate especially where the UK's still-large 'secret state' operates, largely immune to any public or parliamentary scrutiny.

Ros Taylor (@rosamundmtaylor) is Research Manager at the LSE Truth, Trust and Technology Commission and co-editor of LSE Brexit. She is a former Guardian journalist and has also worked for the BBC. 